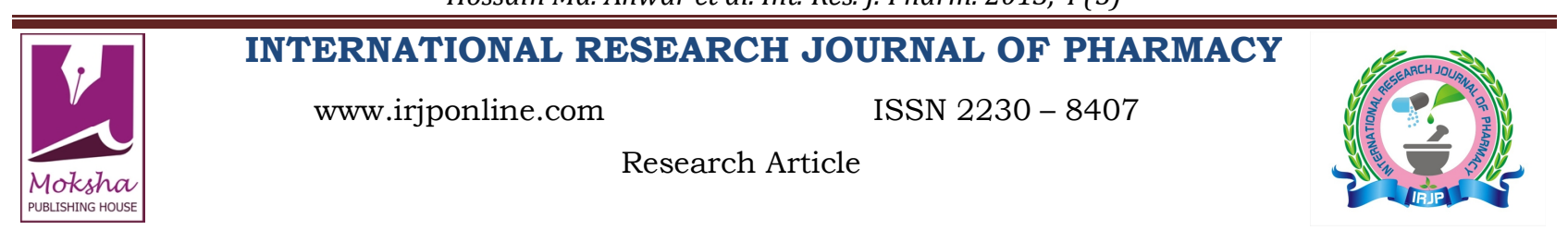

\title{
ASSESSMENT OF PHYTOCHEMICAL AND PHARMACOLOGICAL PROPERTIES OF ETHANOLIC EXTRACT OF CERBERA MANGHAS L. LEAVES
}

Hossain Md. Anwar*, Islam Md. Amirul, Sarker Suman, Rahman Mushfiqur, Siraj Md. Afjalus

Pharmacy Discipline, Life Science School, Khulna University, Khulna-9208, Bangladesh

Email: anwarku_03@yahoo.com

Article Received on: 12/03/13 Revised on: 04/04/13 Approved for publication: 11/05/13

DOI: 10.7897/2230-8407.04524

IRJP is an official publication of Moksha Publishing House. Website: www.mokshaph.com

(C) All rights reserved.

\begin{abstract}
The objective of the present study was to investigate the phytochemical nature (group determination of plant constituents) as well as the antioxidant and analgesic activity of ethanolic extract of the Cerbera manghas L. leaves (Family: Apocynaceae). Phytochemical analysis of ethanolic extract of Cerbera manghas leaves indicated the presence of carbohydrate (reducing sugars), alkaloids, tannins, steroids, flavonoids \& glycosides. The extract exhibited significant $(\mathrm{P}<0.01)$ analgesic effect in acetic acid induced writhing of white albino mice at the dose of $500 \mathrm{mg} / \mathrm{kg}$ body weight. The extract inhibited $30.65 \%$ writhing in mice and it is comparable to the activity of the standard analgesic drug Diclofenac sodium $(79.03 \% \mathrm{P}<0.001)$ at the dose of $25 \mathrm{mg} / \mathrm{kg}$ body weight. The extract showed the antioxidant property by the presence of strong yellow spot on a purple background on the TLC plate and in the free radical scavenging activity study (DPPH assay) the extract showed significant antioxidant activity ( $\mathrm{IC}_{50} \sim 269.15 \mu \mathrm{g} / \mathrm{ml}$ ) which is comparable to standard (Ascorbic Acid, $\mathrm{IC}_{50}$ $\sim 14.45 \mu \mathrm{g} / \mathrm{ml}$ ). The findings suggest that the ethanolic extract of Cerbera manghas leaves possess antioxidant and analgesic activities.

Keywords: Cerbera manghas, Apocynaceae, Antioxidant activity, Analgesic activity, DPPH.
\end{abstract}

\section{INTRODUCTION}

Medicinal plants constitute a precious natural wealth of a country and contribute a great deal to its health care programs. They play a significant role in providing primary health care services to rural people. They serve as important therapeutic agents as well as important raw materials for the manufacture of traditional and modern medicines. According to World Health Organization (WHO) about $80 \%$ of the world population depends on the natural product for their health due to minimal side effect and cost effectiveness ${ }^{1}$.

Cerbera (C.) manghas is a small evergreen coastal tree growing up to 12 meters tall. It is native to Australia, Southeast Asia and some island of polynesia. The shiny darkgreen leaves are alternate, ovoid in shape. The flowers are fragrant, possessing a white, tubular, 5 lobed corollas about 3 to $5 \mathrm{~cm}$ in diameter, with a pink to red throat. There are 5 stamens, and the ovary is positioned above the other flower parts. The fruits are egg-shaped; 2 to 4 inches long resemble mangoes but are extremely bitter, and turn purple-red at maturity. C. manghas is naturally distributed from the Seychelles Islands in the Indian Ocean eastward to French Polynesia. It occupies lowland and coastal habitats and is often associated with mangrove forests. In Bangladesh it is distributed mainly in the Sundarban and southern region.

The leaves and the fruits contain the potent cardiac glycoside cerberin, which is extremely poisonous if ingested. Branches of this tree contain a milky sap which may irritate eyes and skin. People in olden times used the sap of the tree as a poison for animal hunting. Inhaling plant dust while raking C. manghas leaves may irritate nose and throat. People of Philipines eat bark, leaves and milky sap to induce vomiting and as a laxative. Swallowing any part of Cerbera tree particularly fruits can cause nausea, vomiting, abdominal pain and cramping ${ }^{2}$. Deaths may occur following intentional self-poisoning with C. manghas plants ${ }^{3}$. A potent drug cerberin has been extracted from the extremely poisonous seeds; it has some resemblance to digitalis in its effect on the heart, and has been used in medicine in very small amounts ${ }^{4}$. C. manghas possesses strong antioxidant properties ${ }^{5}$. Inhaling smoke from burning C. manghas trees may cause poisoning ${ }^{6}$. Although the plant has widespread traditional use, very little scientific evidences are available. That's why this study was done to establish scientific evidence for analgesic and antioxidant activities of ethanolic extract of $C$. manghas leaves.

\section{MATERIALS AND METHODS}

\section{Collection and Identification}

C. manghas leaves were collected from Dumuria Upazilla in Khulna district, Bangladesh in February, 2011 on the day time. The plant was taxonomically identified by the experts of Bangladesh National Herbarium, Mirpur, Dhaka (Accession no: DCAB-35569) and a voucher specimen was also deposited.

\section{Drying \& Grinding}

The collected plants were separated from undesirable materials or plants or plant parts and these were dried by shade drying for twenty days to ensure the active constituents free from decomposition also to avoid any photochemical degradation. The leaves were ground into a coarse powder with the help of a suitable grinder. The powder was stored in an airtight container and kept in a cool, dark and dry place until analysis commenced.

\section{Extraction}

About $100 \mathrm{gm}$ of powered material was taken in a clean, flatbottomed glass container and soaked in $500 \mathrm{ml}$ of $96 \%$ ethanol. The container with its contents was sealed and kept for a period of 8 days accompanying occasional shaking and stirring. The whole mixture then underwent a coarse filtration by a piece of clean, white cotton material. Then it was filtered through whatman filter paper. The filtrate (ethanol extract) obtained was taken into rotary evaporator to evaporate ethanol. Then this filtrate was taken into a beaker, the opening of beaker was wrapped by a sheet of aluminum foil to which perforation was done for evaporation of the rest of the ethanol \& was kept in dry \& cool place for several days \& 
at last evaporation was done under table fan until dried. It rendered concentrate of deep purple type. The concentrate was designated as crude ethanolic extract.

\section{Experimental Animal}

Young Swiss-albino mice of either sex with average weight 19-25 gm were employed in the experiment taking five in a group. The mice were purchased from the Animal Research Branch of the International Centre for Diarrhoeal Diseases and Research, Bangladesh (ICDDR, B). The mice were kept separately in plastic cages having dimension of $(28 \times 22 \times 13)$ $\mathrm{cm}$. Soft wood shavings were placed in the cages for housing of the mice. The room where the mice were housed was well ventilated for air and light. Husk and excreta were removed from the cages on every day. Fresh water and pellets of mice foods, prepared by ICDDR, B were given to the mice regularly. The mice were kept at least one week in the laboratory to get them adapted with the environment before being employed in any experiment.

\section{Phytochemical Screening}

Small amount of dried extract was appropriately treated to prepare sample solution and then subjected to the specific phytochemical tests. Benedict's test, Fehling's test and Ring test were performed to investigate the presence of reducing sugar. Ferric chloride test and Potassium dichromate test was performed to identify tannin. Frothing test was performed to identify the presence of Saponins. Libermann-Burchard test was performed to identify steroids. Mayer's reagent, Wagner's test and Dragendroff's reagent test was performed to identify alkaloids. For Gums, flavonoid and glycosides general identifying test were performed ${ }^{7}$.

\section{Determination of Analgesic Activity}

The analgesic activity of the crude ethanolic extract of the leaves of C. manghas was studied using acetic acid induced writhing model in mice ${ }^{8-9}$. The animals were divided into control, positive control and test groups with five mice in each group. The animals of test groups received test substance at the dose of $500 \mathrm{mg} / \mathrm{kg}$ body weight. Positive control group was administered with Diclofenac $\mathrm{Na}$ (standard drug) at the dose of $25 \mathrm{mg} / \mathrm{kg}$ body weight and vehicle control group was treated with $1 \%$ Tween 80 in water at the dose of $10 \mathrm{ml} / \mathrm{kg}$ body weight. Test samples, standard drug and control vehicle were administered orally $30 \mathrm{~min}$ before intraperitoneal administration of $0.7 \%$ acetic acid. After an interval of $15 \mathrm{~min}$, the mice were observed writhing (constriction of abdomen, turning of trunk and extension of hind legs) for 5 minutes.

\section{Determination of In-vitro Antioxidant Activity (DPPH Free Radical Scavenging Activity)}

Qualitative Assay: A suitably diluted stock solutions were spotted on pre-coated silica gel TLC plates and the plates were developed in solvent systems of different polarities (polar, medium polar and non-polar) to resolve polar and non-polar components of the extract. The plates were dried at room temperature and were sprayed with $0.02 \% 1$, 1diphenyl-2-picryl hydrazyl (DPPH) in ethanol. Bleaching of
DPPH by the resolved bands was observed for 10 minutes and the color changes (yellow on purple background) were noted $^{10}$. DPPH forms deep pink color when it is dissolved in ethanol. When it is sprayed on the chromatogram of the extract, it forms yellow color which indicates the presence of antioxidants.

Quantitative Assay: The antioxidant potential of the ethanol extract was determined on the basis of their scavenging activity of the stable 2, 2-diphenyl-1-picryl hydrazyl (DPPH) free radical. DPPH is a stable free radical containing an odd electron in its structure and usually utilized for detection of the radical scavenging activity in chemical analysis. The aliquots of the different concentrations $(1.57,3.13,6.25,12$. $5,25,50,100,200$ and $400 \mu \mathrm{g} / \mathrm{ml})$ of the extract were added to $6 \mathrm{~mL}$ of a $0.004 \% \mathrm{w} / \mathrm{v}$ solution of DPPH. After 30 minutes, absorbance was determined by UV spectrophotometer at $517 \mathrm{~nm}$ and $\mathrm{IC}_{50}$ (Inhibitory conc. 50\%) was determined. $\mathrm{IC}_{50}$ value denotes the concentration of sample required to scavenge $50 \%$ of the DPPH free radicals ${ }^{11}$. The formula used to calculate $\%$ inhibition is;

$\%$ inhibition $=$

[(Blank absorbance - Sample absorbance) / Blank absorbance] X 100

\section{RESULTS}

The ethanolic extract of C. manghas leaves was subjected to different qualitative phytochemical tests for detection of different groups of biologically active chemical compounds and the results are summarized in the Table 1 . Table 2 shows the effect of the ethanolic extract of the leaves of $C$. manghas on acetic acid induced writhing in mice. At the dose of 500 $\mathrm{mg} / \mathrm{kg}$ of body weight, the extract produced $30.65 \%$ writhing inhibition in test animals. The results were statistically significant $(\mathrm{P}<0.01)$ and was comparable to the standard drug Diclofenac $\mathrm{Na}$, which showed $79.03 \%$ writhing inhibition at a dose of $25 \mathrm{mg} / \mathrm{kg}$ weight.

In the TLC-based qualitative antioxidant assay using DPPH, C. manghas leaves showed the free radical scavenging properties indicated by the presence of strong yellow spot on a purple background on the TLC plate.

In the quantitative assay, $C$. manghas leaves displayed a significant free radical scavenging activity in the DPPH assay $\left(\mathrm{IC}_{50} \sim 269.15 \mu \mathrm{g} / \mathrm{ml}\right.$ ) which is comparable to that of ascorbic acid $\left(\mathrm{IC}_{50} \sim 14.45 \mu \mathrm{g} / \mathrm{ml}\right.$ ), (Table 3, Table $4 \&$ Fig. 1), a wellknown standard antioxidant.

\section{DISCUSSION}

The peripheral analgesic effect of the plant's extract may be mediated via inhibition of cyclooxygenases and/or lipoxygenases (and other inflammatory mediators), while the central analgesic action of the extract may be mediated through inhibition of central pain receptors. This is based on the hypothesis that acetic acid-induced writhing and hot-plate test methods are useful techniques for the evaluation of peripherally- and centrally-acting analgesic drugs, respectively ${ }^{12-13}$. On the basis of the result of acetic acid induced writhing test, it could be concluded that the ethanolic extract of the leaves of $C$. manghas might possess an analgesic activity. 
Table 1: Results of phytochemical group tests

\begin{tabular}{|c|c|c|c|c|c|c|c|c|}
\hline Extract & Alkaloids & Steroids & Saponins & Reducing sugar & Tanins & Gums & Flavonoids & Glycosides \\
\hline Ethanol & + & + & - & + & + & - & + & + \\
\hline
\end{tabular}

Table 2: Effect of $C$. manghas extract on acetic acid induced writhing in mice

\begin{tabular}{|c|c|c|c|}
\hline Group & Treatment and Dose & Number of writhes ( \% Writhing) & \% Writhing Inhibition \\
\hline Control & $1 \%$ tween 80 solution $10 \mathrm{ml} / \mathrm{kg}$, p.o. & $24.8 \pm 3.35(100)$ & - \\
\hline Positive Control & Diclofenac Na $25 \mathrm{mg} / \mathrm{kg}, \mathrm{p} . \mathrm{o}$. & $5.2 \pm 3.03(20.97)$ & $79.03^{* *}$ \\
\hline Test Group & Et. Extract of $C$. manghas $500 \mathrm{mg} / \mathrm{kg}$, p.o. & $17.2 \pm 3.63(69.35)$ & $30.65^{*}$ \\
\hline
\end{tabular}

Values are expressed as mean \pm SEM (Standard Error of Mean); $(\mathrm{n}=5) \mathrm{n}=$ number of mice; $* * \mathrm{P}<0.001,{ }^{*} \mathrm{P}<0.01$, p.o. $=$ per oral.

Table 3: DPPH scavenging assay of $C$. manghas

\begin{tabular}{|c|c|c|c|c|c|}
\hline Conc. Of Extract $(\mu \mathrm{g} / \mathrm{ml})$ & log conc. & Absorbance1 & Absorbance2 & Average & \% inhibition \\
\hline 1.57 & 0.196 & 0.70 & 0.731 & 0.71 & 1.25 \\
\hline 3.13 & 0.496 & 0.690 & 0.689 & 0.689 & 4.17 \\
\hline 6.25 & 0.796 & 0.683 & 0.679 & 0.681 & 5.29 \\
\hline 12.5 & 1.097 & 0.671 & 0.669 & 0.670 & 6.82 \\
\hline 25 & 1.398 & 0.667 & 0.661 & 0.664 & 7.65 \\
\hline 50 & 1.699 & 0.606 & 0.605 & 0.606 & 15.72 \\
\hline 100 & 2 & 0.54 & 0.47 & 0.51 & 29.07 \\
\hline 200 & 2.301 & 0.39 & 0.40 & 0.39 & 45.76 \\
\hline 400 & 2.602 & 0.29 & 0.35 & 0.32 & 55.49 \\
\hline
\end{tabular}

Table 4: DPPH scavenging assay of ascorbic acid

\begin{tabular}{|c|c|c|c|c|c|}
\hline Conc. of Extract $(\mu \mathrm{g} / \mathrm{ml})$ & log conc. & Absorbance1 & Absorbance2 & Average & \% inhibition \\
\hline 1.57 & 0.196 & 0.713 & 0.705 & 0.709 & 1.39 \\
\hline 3.13 & 0.496 & 0.71 & 0.63 & 0.67 & 6.82 \\
\hline 6.25 & 0.796 & 0.562 & 0.560 & 0.564 & 21.56 \\
\hline 12.5 & 1.097 & 0.391 & 0.395 & 0.393 & 45.34 \\
\hline 25 & 1.398 & 0.22 & 0.22 & 0.22 & 69.40 \\
\hline 50 & 1.699 & 0.093 & 0.081 & 0.087 & 87.90 \\
\hline 100 & 2 & 0.053 & 0.049 & 0.051 & 92.91 \\
\hline
\end{tabular}

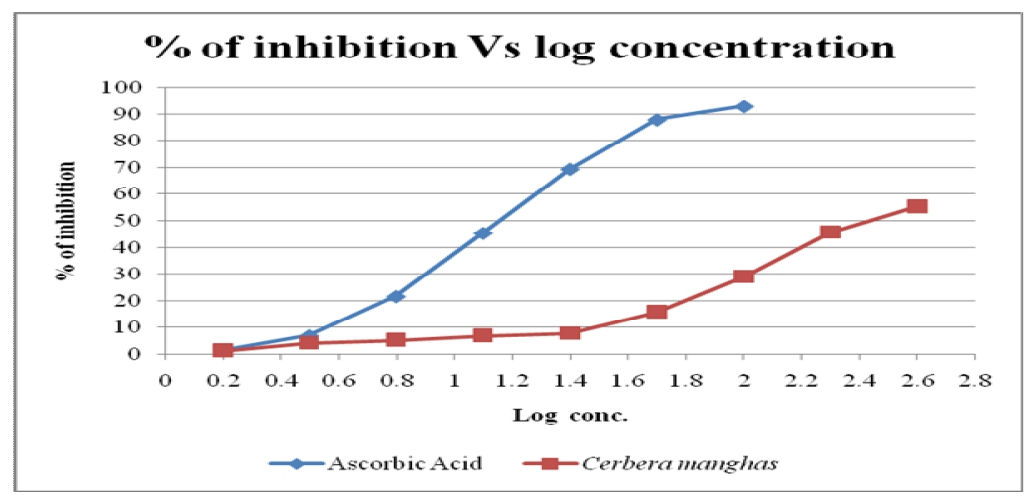

Figure 1: Comparison of \% inhibition vs. Log concentration graph for standard (Ascorbic Acid) vs. C. manghas

The DPPH radical contains an odd electron which is responsible for visible purple color. When DPPH accepts an electron donated by an antioxidant compound, the DPPH is decolorized \& observed as light yellow spot. C. manghas leaves extract may contain some anti-oxidative compounds which give an electron \& produce light yellow color. Therefore quantitative determination is necessary to find out the extent of antioxidant activity. $0.02 \% \mathrm{DPPH}$ solution in ethanol is sprayed onto a TLC plate, the compounds having antioxidant properties are seen as yellow zones on a purple background $^{14}$. After applying DPPH on the TLC plate, yellow color on purple background was observed which indicated the presence of antioxidant components in the ethanol extract of the leaves of $C$. manghas. The flavonoids from plant extracts have been found to possess antioxidants and anti-inflammatory properties in various studies ${ }^{15-16}$. Several plant components like tannins are responsible for showing antioxidant property ${ }^{17}$. As in the phytochemical group test, $C$. manghas leaves showed the presence of flavonoids and tannins, its antioxidant and anti-inflammatory properties may be observed due to the presence of these chemical components.

\section{CONCLUSION}

The results found in different experiments showed that the ethanolic extract of $C$. manghas leaves possesses organic compounds like- reducing sugars, steroid, alkaloid, glycoside, flavonoid \& tannin. In analgesic test the extract produced moderate writhing inhibition comparable to standard drug Diclofenac sodium which indicates significant analgesic activity. The extract showed the free radical scavenging properties indicated by the presence of strong yellow spot on a purple background on the TLC plate. In the quantitative assay, the extract displayed free radical scavenging activity in 
the DPPH assay which is comparable to that of ascorbic acid a well-known standard antioxidant. The potential of the extract of $C$. manghas leaves as antioxidants may be due to the presence of phytoconstituents like flavonoids and tannins. However, extensive researches are necessary to search for active principles responsible for these activities.

\section{ACKNOWLEDGEMENT}

Authors are grateful to the Authority of the Khulna University for giving the opportunity to conduct such experiment and providing necessary chemical, instrument and utility support. Authors are also thankful to Mr. Hafizur Rahman for financial support for publication.

\section{REFERENCES}

1. Siraj MA, Hossain E, Das KK, Safi S, Yasmin F: Assessment of antidiarrhoeal, analgesic and antibacterial activity of ethanolic extract of Ecbolium linneanum (Acanthaceae) leaves. Int. J. of Pharmaceutical Sci. Invention 2013; 2 (2):41-46

2. Scott S, Thomas MD Craig. Poisonous Plants of Paradise: First Aid and Medical Treatment of Injuries from Hawaii's Plants. University of Hawaii Press, Honolulu, Edition 1, 2000: 37.

3. Eddleston $\mathrm{M}$, Persson $\mathrm{H}$ : Acute plant poisoning and antitoxin antibodies. J Toxicol Clin Toxicol. 2003; 41(3): 309-15. http://dx.doi.org/10.1081 /CLT-120021116

4. Barceloux DG: Medical Toxicology of Natural Substances: Foods, Fungi, Medicinal Herbs, Plants, and Venomous Animals. Wiley, Edition 1, 2012: 857 .

5. Lee SK, Mbwambo ZH, Chung H, Luyengi L, Gamez EJ, Mehta RG, Kinghorn AD, Pezzuto JM: Evaluation of the antioxidant potential of natural products. Comb Chem High Throughput Screen. 1998; 1(1): 35 46.

6. Scott S, Thomas MD Craig: Poisonous Plants of Paradise: First Aid and Medical Treatment of Injuries from Hawaii's Plants. University of Hawaii Press, Honolulu, Edition 1, 2000:38.

7. Islam MA, Saifuzzaman M, Ahmed F, Rahman MM, Sultana NA, Naher K: Antinociceptic activity of methanolic extract of Acanthus ilicifolius Linn. Leaves. Tur J. Pharm Sci. 2012; 9(1): 51-60
8. Whittle BA: The use of changes in capillary permeability in mice to distinguish between narcotic and non-narcotic analgesics; $\mathrm{Br}$. J. Pharmacol. Chemother., 1964; 22: 246-249. http://dx.doi.org/10.1111 /j.1476-5381.1964.tb02030.x

9. Ahmed F, Selim MST, Das AK, Choudhuri MSK: Anti-inflammatory and antinociceptive activities of Lippia nodiflora Linn; Pharmazie., 2004; 59:329-333.

10. Hai-Feng Gu, Chun-Mei Li, Yu-juan Xu, Wan-feng Hu, Mei-hong Chenand Qiong-hong Wan: Structural features and antioxidant activity of tannin from persimmon pulp. Food Research International 2008; 41(2): 208-217. http://dx.doi.org/10.1016/j.foodres.2007.11.011

11. Jain V., S.K. Verma, S.S. Katewa, S. Anandjiwala and B. Singh: Free radical scavenging property of Bombax ceiba Linn. root. Res. J. Med. Plant 2011; 5(4): 462-470. http://dx.doi.org/10.3923/rjmp.2011.462.470

12. Koster R, Anderson M, De-Beer EJ: Acetic acid for analgesic screening; Fed. Proceed., 1959; 18:412-418.

13. Williamson EM, Okpako DT, Evans FJ: Pharmacological Methods in Phytotherapy Research: Selection, preparation and pharmacological evaluation of plant material; John Willey and Sons, England, Edition 1, Vol. 1, 1996:131-184.

14. Çiğdem ALTINYAY, Ayșegul GUVENC, Mehmet Levent ALTUN: Antioxidant Activities of Oleuropein and the Aqueous Extracts of Olea europaea L. Varieties Growing in Turkey. Turk J. Pharm. Sci. 2011; 8 (1): 23-30.

15. Lin Y, Shi R, Wang X, Shen HM: Luteolin, a flavonoid with potential for cancer prevention and therapy. Curr. Can. Drug Targ. 2008; 8: 63446. http://dx.doi.org/10.2174/156800908786241050

16. Lopez-Lazaro M: Distribution and biological activities of the flavonoid luteolin. Mini Rev. Med. Chem. 2009; 9: 31-59. http://dx.doi.org $/ 10.2174 / 138955709787001712$

17. Liang-liang Zhang and Yi-ming Lin: Tannins from Canarium album with potent antioxidant activity. J Zhejiang Univ Sci B. 2008; 9(5): 407415. http://dx.doi.org/10.1631/jzus.B0820002

\section{Cite this article as:}

Hossain Md. Anwar, Islam Md. Amirul, Sarker Suman, Rahman Mushfiqur, Siraj Md. Afjalus. Assessment of phytochemical and pharmacological properties of ethanolic extract of Cerbera manghas L. leaves. Int. Res. J. Pharm. 2013; 4(5):120-123 